\title{
PERAN SOCIAL SKILL TRAINING DALAM MENINGKATKAN KETERAMPILAN SOSIAL PASIEN SKIZOFRENIA KATATONIK
}

\author{
Muhamad Febrian Al Amin1 \\ Universitas Muhammadiyah Malang, \\ Kota Malang, Jawa Timur, Indonesia
}

\begin{abstract}
This study aimed to determine the role of social skill training in improving social skills. Data collection methods used in this study are interviews, WAIS testing, projective test, and SSCT. The subject of the study was an 18 years old male who had a catatonic schizophrenic disorder who did not want to interact socially before entering Menur Psychiatric Hospital. The intervention given was Social Skill Training to improve social skills in 7 sessions. Through Social Skill Training, subjects are trained in various social skills, such as greeting, introducing themselves, communicating lightly and to make friends so that the subject is no longer to be silent and sculpting in the room and make the subject be able to go to school again. The results showed a number of changes, such as subjects who were able to greet, introduce themselves first, even able to have small conversations with people around the subject.
\end{abstract}

Keywords: Diathesis Stress, Schizophrenia, Social Skill Training

\begin{abstract}
ABSTRAK: Penelitian ini dimaksudkan untuk mengetahui peranan Social Skill Training dalam meningkatkan keterampilan sosial. Metode pengumpulan data yang dilakukan pada penelitia ini adalah wawancara, pemberian tes WAIS, Grafis, dan SSCT. Subjek penelitian adalah seorang lakilaki berusia 18 tahun yang mengalami gangguan skizofrenia katatonik yang sebelum masuk RSJ Menur sama sekali tidak mau berinteraksi sosial. Intervensi yang diberikan adalah Social Skill Training untuk meningkatkan keterampilan sosial yang dilakukan sebanyak 7 sesi. Melalui Social Skill Training, subjek dilatih berbagai ketrampilan sosial, seperti mengucap salam, memperkenalkan diri, berkomunikasi ringan dan hingga menjalin pertemanan sehingga subjek tidak lagi sering diam mematung berada di kamar dan membuat subjek bisa bersekolah lagi. Hasil penelitian menunjukkan adanya beberapa perubahan, seperti subjek yang mampu menyapa, memperkenalkan diri terlebih dahulu, bahkan mampu mengobrol ringan dengan orang yang berada di sekitar subjek.
\end{abstract}

Kata kunci: Diathesis Stress, Skizofrenia, Social Skill Training

\footnotetext{
${ }^{1}$ Korespondensi mengenai artikel dapat melalui muhamadfebrian95@gmail.com
} 
Skizofrenia didefinisikan sebagai penyakit mental dengan gangguan otak yang kompleks. Skizofrenia adalah suatu penyakit pervasif yang mempengaruhi lingkup yang luas dari proses psikologis mencakup kognisi, afek, dan perilaku. Mereka kehilangan jati diri dan mengalami kegagalan dalam menjalankan peran dan fungsinya di dalam masyarakat. Pikiran dan perasaan yang tidak seimbang menyebabkan penderita skizofrenia terputus dari realitas (Nevid, Rathus, \& Beverly, 2002). Skizofrenia adalah suatu psikosis fungsional dengan gangguan utama pada proses pikir serta disharmonisasi antara proses pikir, afek atau emosi, kemauan dan psikomotor disertai distorsi kenyataan, terutama karena waham dan halusinasi, assosiasi terbagi-bagi sehingga muncul inkoherensi, afek dan emosi inadekuat, serta psikomotor yang menunjukkan penarikan diri (Maramis, 2009).

Pada fase awal atau prodormal penderita akan terlihat murung, menarik diri dari lingkungannya, sedikit bicara, dan malas dalam beraktivitas. Dari sini akan terjadi penurunan peran dan fungsi dalam sosial kemasyarakatan. Fase ini sering tidak disadari oleh keluarga, teman dekat atau bahkan penderita skizofrenia sendiri. Secara tidak sadar penderita akan memasuki fase berikutnya, yaitu fase akut saat mereka mengalami waham dan halusinasi

Gejala skizofrenia dibagi menjadi dua kategori utama, yaitu gejala positif dan gejala negatif. Gejala positif terdiri atas delusi (waham), halusinasi dan perilaku aneh (Videbeck, 2008). Gejala negatif (defisit perilaku) meliputi afek tumpul dan datar, menarik diri dari masyarakat, tidak ada kontak mata, tidak dapat mengekpresikan perasaan, tidak mampu berhubungan dengan orang lain, dan motivasi menurun. Gejala negatif pada skizofrenia dapat menyebabkan klien mengalami gangguan fungsi sosial dan isolasi sosial. Gejala positif dapat dikontrol dengan pengobatan, tetapi gejala negatif seringkali menetap sepanjang waktu dan menjadi hambatan utama pemulihan dan perbaikan fungsi dalam kehidupan sehari-hari (Videbeck, 2008).

Ada beberapa kategori dalam skizofrenia salah satunya adalah skizofrenia katatonik. Menurut Maramis (2004), skizofrenia katatonik atau disebut juga katatonia, timbulnya pertama kali antara umur 15-30 tahun dan biasanya akut serta sering didahului stres emosional. Mungkin terjadi gaduh gelisah katatonik atau stupor katatonik dan ciri diam dan membisu. Pada stupor katatonik, penderita tidak menunjukkan perhatian sama sekali terhadap lingkungannya dan emosinya sangat dangkal. Secara tiba-tiba atau perlahan-lahan penderita keluar dari keadaan stupor ini dan mulai berbicara dan bergerak. Pada gaduh gelisah katatonik, terdapat hiperaktivitas motorik, tapi tidak disertai dengan emosi yang semestinya dan tidak dipengaruhi rangsangan dari luar.

Dewasa ini skizofrenia katatonik jarang ditemukan, mungkin karena terapi obat bekerja secara efektif bagi prosesproses motorik yang aneh tersebut. Meskipun terapi obat mampu bekerja secara efektif, tetap saja hal tersebut sangat dipengaruhi faktor lingkungan dan pembelajaran sosial. Onset reaksi katatonik dapat lebih tiba-tiba dibanding skizofrenia yang lain, meskipun orang yang bersangkutan sebelumnya telah menunjukkan semacan menarik diri dari kenyataan.

\section{Social Skill Training}

Kondisi subjek skizofrenia katatonik memang banyak tidak mengganggu dan tidak merusak lingkungan, tetapi banyak aktivitas sosial yang terabaikan, salah satu terapi yang tepat untuk pasien tipe katatonik adalah social skill training (pelatihan 
keterampilan sosial). Keterampilan sosial sendiri dapat diartikan sebagai kemampuan individu untuk berkomunikasi efektif dengan orang lain baik secara verbal maupun nonverbal sesuai dengan situasi dan kondisi yang ada pada saat itu, di mana keterampilan ini merupakan perilaku yang dipelajari. Gimpel dan Merrel (1998) mendefinisikan keterampilan sosial sebagai perilaku-perilaku yang dipelajari, yang digunakan individu pada situasi-situasi interpersonal dalam lingkungan.

Social Skill Training (SST) mengajarkan tiga kemampuan sosial yakni: 1) kemampuan berkomunikasi, yaitu bagaimana kemampuan menggunakan bahasa tubuh yang tepat, mengucapkan salam, memperkenalkan diri, menjawab pertanyaan, menginterupsi pertanyaan dengan baik, dan kemampuan bertanya; 2) kemampuan menjalin persahabatan, yaitu menjalin pertemanan, mengucapkan dan menerima ucapan terima kasih, memberikan dan menerima pujian, terlibat dalam aktifitas bersama, berinisiatif melakukan kegiatan dengan orang lain, meminta dan memberikan pertolongan; 3) kemampuan dalam menghadapi situasi sulit, yaitu memberikan kritik dan menerima penolakan, bertahan dalam tekanan kelompok dan minta maaf (McQuaid, 2000). Berdasarkan uraian tersebut, intervensi ini ingin melihat sejauh mana keterampilan sosial pada orang yang mengalami gangguan skizofrenia dapat ditingkatkan dengan pemberian intervensi pelatihan keterampilan sosial (social skill training) dengan teknik modeling.

\section{Model Diathesis Stress}

Menurut sudut pandang ilmu perilaku, skizofrenia terjadi salah satunya berkaitan dengan pola asuh orang tua yang diterapkan kepada anaknya, yaitu berupa pola asuh patogenik. Skizofrenia berasal dari perilaku keluarga, terutama keluarga patologis, yang secara signifikan meningkatkan stres emosional yang harus dihadapi pasien skizofrenia. Menurut pandangan ini, anak-anak yang nantinya mengalami skizofrenia mempelajari reaksi dan cara berpikir yang tidak rasional dengan mengimitasi orang tua yang juga memiliki masalah emosional yang signifikan. Hubungan interpersonal yang buruk dari pasien skizofrenia berkembang karena pada masa anak-anak mereka belajar dari model yang buruk.

Ajaran di dalam Islam pun telah membahas tentang tanggung jawab orang tua atas pola asuh terhadap anak, sebagaimana disebutkan dalam Al-Qur'an surah al-Anfal ayat 28.

"Dan ketahuilah bahwa hartamu dan anak-anakmu itu hanyalah sebagai cobaan dan sesungguhnya disisi Allahlah pahala yang besar."

Ayat di atas menjelaskan salah satu ujian yang diberikan Allah kepada orang tua adalah anak-anak mereka. Itulah sebabnya setiap orangtua hendaklah benar-benar bertanggung jawab terhadap amanah yang diberikan Allah Swt sekaligus menjadi batu ujian yang harus dijalankan. Jika anak yang dididik mengikuti ajaran Islam maka orangtua akan memperoleh ganjaran pahala yang besar dari hasil ketaatan mereka.

Dinamika terbentuknya gangguan skizofrenia pada subjek yang dilihat dari faktor penyebabnya dapat dijelaskan melalui model diathesis stress. Berdasarkan perspektif diathesis stress, individu dapat mengalami gangguan patologis seperti psikotik disebabkan adanya interaksi antara kerentanan genetik, kepribadian dan stresor lingkungan (Myin-Germeys et al, 2001; Brennan \& Walker, 2001). Dalam diathesis stress gangguan yang dialami seseorang dapat dipengaruhi faktor genetis atau neurotis, lingkungan dan psikologis.

Penyebab terjadinya gangguan pada diri subjek karena kerentanan psikologis 
yaitu masalah kepribadiannya. Kepribadian subjek yang tertutup, cenderung pasif dalam tindakan dan sangat bergantung pada dorongan serta perhatian orang lain membuat subjek mudah tertekan ketika menghadapi stressor. Kemampuan sosial subjek yang rendah membuat subjek menarik diri dari lingkungan sekitar. Faktor lingkungan juga mendukung seperti pola asuh sangat permisif membuat subjek tidak tahu dan tidak pernah belajar coping stress.

Memiliki diathesis stress dapat meningkatkan resiko seseorang mengalami gangguan. Selain itu secara umum stress juga dapat mengarah pada stimulus yang menyebabkan psikopatologis. Dalam diathesis stress gangguan yang dialami seseorang tidak mungkin disebabkan faktor tunggal namun ada faktor lainnya yang juga berperan dalam gangguan. Faktor - faktor tersebut seperti karakteristik kepribadian, pengalaman masa kecil, strategi menghadapi stress, stressor yang dialami dimasa dewasa serta berbagai faktor lainnya (Davidson, Neale \& Kring, 2006). Model diathesis stress memandang skizofrenia sebagai interaksi atau kombinasi dari diathesis, dalam bentuk predisposisi genetis maupun psikologis untuk berkembangnya gangguan dengan stres lingkungan yang melebihi batas atau coping individu. Stressor lingkungan mencakup faktor psikologis seperti konflik keluarga, perlakuan yang salah terhadap anak, atau kehilangan figur yang memberikan dukungan dan lain sebagainya (Nevid, Rathun \& Greene, 2005).

Dinamika terbentuknya masalah pada subjek dapat dijelaskan melalui perspektif behavioral. Perspektif behaviorisme mengemukakan bahwa individu dan lingkungan merupakan dua hal yang saling berkaitan dan memengaruhi satu sama lain untuk menciptakan sebuah perilaku (Bandura, 1977). Dalam hal ini lingkungan subjek tidak memberikan hal positif terhadap subjek, seperti orang tua subjek acuh dan permisif karena jarang berkomunikasi sehingga subjek sehingga subjek menjadi sosok yang tertutup dan lebih banyak menghabiskan waktu di dalam kamar. Kebiasaan subjek juga banyak diam di kamar dan tidak ada komunikasi dengan keluarga atau sekitarnya, menjadikan subjek tidak sempat mengungkapkan pendapatnya.

Hal-hal di atas membuat subjek menjadi seseorang yang kurang dalam hal keterampilan sosialnya. Hal ini terbukti saat di RSJ, subjek lebih sering barada di kamar dan enggan untuk berinteraksi dengan lingkungan sekitar. Untuk menghadapi keadaan ini, perlu dilakukan pelatihan ketrampilan sosial. Pelatihan keterampilan sosial dimaksudkan agar individu meningkat untuk berkomunikasi efektif dengan orang lain baik secara verbal maupun nonverbal sesuai dengan situasi dan kondisi yang ada pada saat itu. Ketrampilan ini merupakan perilaku yang dipelajari. Pelatihan keterampilan sosial mengajarkan tiga kemampuan sosial yakni: 1) kemampuan berkomunikasi, 2) kemampuan menjalin pertemanan, 3) kemampuan dalam menghadapi situasi sulit (MqQuaid, 2000). Dalam penelitian ini, pelatihan hanya berfokus pada kemampuan menjalin pertemanan seperti Mampu menyapa, memperkenalkandiri, berkomunikasi ringan dengan lingkungan sekitar.

Keterampilan sosial sejalan dengan teori belajar sosial dari Bandura yang mengemukakan bahwa individu mempelajari sesuatu melalui pengalaman langsung atau observasi (Bandura, 1986) dalam hal ini dengan menggunakan teknik modeling sehinga subjek mampu mempelajari hal baru dengan cara mencontoh perilaku yang ada di sekitarnya. Menurut Bandura, proses mengamati dan meniru perilaku dan sikap orang lain sebagai model merupakan tindakan belajar. Teori Bandura menjelaskan perilaku manusia dalam konteks interaksi timbal balik yang berkesinambungan antara kognitif, perilaku 
dan pengaruh lingkungan. Kondisi lingkungan sekitar individu sangat berpengaruh pada pola belajar sosial jenis ini.

Teori pembelajaran sosial merupakan perluasan dari teori belajar perilaku yang tradisional (behavioristik). Teori pembelajaran sosial ini dikembangkan Albert Bandura (1986). Teori belajar sosial mengemukakan bahwa individu mempelajari sesuatu melalui pengalaman langsung atau observasi (Bandura, 1986). Proses pengamatan ini tentunya tidak berlangsung begitu saja, melainkan melibatkan fungsi kognitif individu. Olehsebab itu, perilaku sederhana cenderung mudah untuk ditiru (Bandura, 1989). Proses pengamatan dan pembelajaran keterampilan sosial dalam bentuk sederhana ini diharapkan mampu diikuti dengan baik oleh subjek agar dapat mengalihkan pemikiran negatifnya.

Berdasarkan penjelasan di atas dapat dirumuskan tujuan penelitian, yaitu mengetahui peranan pelatihan ketrampilan sosial dalam meningkatkan ketrampilan sosial skizofrenia.

\section{METODE PENELITIAN}

\section{Subjek Penelitian}

Subjek adalah seorang laki-laki berusia 18 tahun yang mengalami gangguan skizofrenia katatonik. Permasalahan subjek adalah semenjak putus sekolah subjek sering berdiam diri di kamar dan diam saja seperti mematung, tidak mau turun dari ranjang. Selama 6 bulan sebelum datang ke RSJ Menur, subjek sama sekali tidak mau berinteraksi sosial.

\section{Metode Pengumpulan Data}

Proses pengumpulan data subjek dilakukan dengan metode observasi, wawancara, dan tes psikologi. Observasi dilakukan pada saat wawancara dan observasi keadaan keluarga pada waktu berkunjung kerumah subjek, tujuan dari penggunaan metode observasi untuk melihat pola perilaku subjek sehari-hari. Wawancara dilakukan dengan subjek (autoanamnesa) dan keluarga, perawat, dokter (allowanamnesa) yang bertujuan untuk mengumpulkan data data terkait dengan subjek. Tes psikologi meliputi tes Grafis yang diberikan terdiri dari BAUM, HTP, DAP untuk mengungkap kepribadian dan dinamika subjek yang ada kaitan dengan permasalahannya.

Tes psikologi Wescler Adult Inteligence Scale (WAIS) yang digunakan untuk memprediksikan potensi-potensi psikologis penunjang dari IQ itu sendiri yang dipengaruhi faktor: lingkungan, latihan, motivasi, dan minat.Walaupun hasil dari tes WAIS ini berupa angka inteligensi, baik yang berupa Full IQ, Verbal IQ maupun Performance IQ; namun diketahui juga bahwa subtes yang terdapat dari tes WAIS dapat digunakan untuk memprediksikan permasalahan klinis yang dialami seseorang, baik untuk memprediksikan kemungkinan adanya brain damage, cronic alkoholism, mental retarded. Tes psikologi Sack's Sentence Completion Test (SSCT) digunakan untuk mengungkap masalah - masalah yang muncul pada diri subjek.

\section{Prosedur Intervensi}

Model social skill training (SST) dengan mengacu pada 4 (empat) tahapan social skills training yang dikemukakan Stuart dan Laraia (2005), yakni melatih kemampuan klien berkomunikasi, menjalin persahabatan dan menghadapi situasi sulit, dengan menggunakan metode modelling, role play, feedback dan transfer training. Sistem tersebut teridentifikasi oleh tindakan dan perilaku yang teratur dan terkontrol faktor-faktor biologis, psikologis, dan sosiologis.

Pada kasus ini, intervensi yang digunakan adalah terapi perilaku dengan target untuk meningkatkan ketrampilan sosial seperti menyapa, memperkenalkan 
diri berkomunikasi ringan dengan lingkungan. Terapi perilaku berupa keterampilan sosial merupakan salah satu intervensi dengan teknik modifikasi perilaku yang didasarkan pada prinsipprinsip bermain peran, praktek dan umpan balik guna meningkatkan kemampuan klien dalam menyelesaikan masalah pada klien depresi, skizofrenia, klien dengan gangguan perilaku kesulitan berinteraksi, mengalami fobia sosial dan klien yang mengalami kecemasan (Kneisl, 2004, Stuart \& Laraia, 2005, Varcarolis, 2006).

Intervensi ini berjalan dalam 7 sesi. Sesi pertama: Membangun Rapport dengan subjek, pada sesi ini terapis berusaha membuat subjek nyaman dan percaya kepada terapis agar intervensi tersebut berjalan dengan lancar.

Sesi kedua: Orientasi pengenalan terapi dan identifikasi pemicu masalah, pada sesi ini subjek dikenalkan tentang terapi yang akan terapis berikan, yaitu berupa pelatihan keterampilan sosial. Terapis juga menjelaskan prosedur apa saja yang akan dilalui oleh subjek selama terapi dan subjek harus memperhatikan instruksi yang terapis berikan. Pada sesi ini juga terapis mengajak subjek membuat target perubahan yang akan dicapai yaitu untuk meningkatkan keterampilan sosial subjek yaitu mampu mengucap salam, memperkenalkan diri, berkomunikasi ringan dan tidak lagi sering berada di kamar.Pada sesi ini terapis meminta subjek untuk mengenali masalah atau situasi yang dapat membuat subjek memilih untuk menarik diri dan berdiam diri di dalam kamar. Terapis juga memberikan penjelasan tentang dampak yang akan terjadi jika subjek memilih untuk menarik diri dan berdiam diri di dalam kamar setelah menonton video.

Sesi ketiga: Modelling, terapis mengajarkan subjek keterampilan dengan cara memberikan contoh terlebih dahulu. Terapis mencontohkan bagaimana cara menyapa, berkenalan dan menanyakan kabar kepada orang-orang yang berada dalam lingkungan bangsal subjek, kemudian terapis menyuruh subjek untuk memperhatikan apa yang terapis lakukan agar dapat dicontoh dan dilakukan. Pada sesi ini subjek mengamati bagaimana cara berinteraksi ringan yang terapis contohkan seperti bagaimana cara tersenyum, menyapa, berkenalan dan menanyakan kabar orang-orang yang berada di lingkungan subjek agar dapat dipraktekkan pada sesi selanjutnya.

Sesi keempat: Role play. Terapis meminta subjek untuk mencoba menghampiri orang yang berada di sekitarnya, kemudian subjek diminta tersenyum lebih dulu kepada orang tersebut, menyapa, berkenalan, menanyakan kabar.

Sesi kelima: Pemberian Tugas. Terapis meminta subjek melakukan interaksi dengan lingkungan subjek tanpa ditemani oleh terapis. Terapis juga meminta subjek agar dapat berkomunikasi ringan dengan orang-orang sekitar subjek. Setelah 4 kali pertemuan subjek baru mampu melakukan tugas yang diberikan oleh terapis dengan baik. Subjek mampu berkomunikasi ringan dengan orang-orang sekitar subjek, sehingga subjek tidak hanya berada di dalam kamar

Sesi keenam: Evaluasi. Terapis mengevaluasi kegiatan yang dilakukan subjek, terapis memberikan umpan balik kepada subjek dan memberikan penguatan terus menerus kepada subjek dengan mengatakan bahwa apa yang telah subjek lakukan sudah baik dan benar, sehingga subjek mampu memenuhi target perubahan yang telah dibuat yaitu, subjek sudah mampu menyapa, berkenalan bahkan menanyakan kabar, subjek merasa tidak sendiri dan memiliki banyak temanorang yang sayang dan peduli kepada subjek.

Sesi ketujuh: Terminasi. Pada sesi ini terapis menyimpulkan hal-hal yang telah dipelajari subjek selama proses intervensi, 
memberikan bekal perilaku agar subjek mau membiasakan diri untuk bersosialisai dengan lingkungan dan meningkatkan interaksi sosial subjek agar merasa tidak sendiri dalam menghadapi masalah . Terapis juga meminta pada perawat untuk tetap mengontrol subjek meskipun proses intervensi sudah berakhir. Terminasi ini dilakukan ketika target perubahan yang diinginkan yaitu ketika keterampilan sosial subjek untuk meningkatkan interaksi sosial subjek sudah meningkat.

Sesi kedelapan: Follow-up dua minggu setelah intervensi berakhir. Followup dilakukan untuk mengetahui perkembangan subjek dalam interaksinya terhadap lingkungan sosial subjek. Saat follow up subjek bahkan sudah sering berkomunikasi bahkan menjalin pertemanan dengan orang-orang sekitar.

\section{Hasil Penelitian}

Berdasarkan pelaksanaan intervensi yang telah dilakukan, subjek sudah mulai menunjukkan perubahan secara bertahap. Setelah intervensi subjek yang awalnya lebih banyak diam dan sering mengurung diri di dalam kamar sudah mau untuk keluar kamar dan berinteraksi dengan orang di sekitar subjek. Subjek juga sudah mau mulai menyapa dan mengajak berkenalan orang yang berada di sekeliling subjek. Subjek juga sudah mulai terlibat obrolan dengan keluarga dan sepupu-sepupunya yang berada di rumah.

Subjek juga menyadari bahwa sikap subjek yang selama ini hanya diam, tertutup dan enggan berkomunikasi dengan orangorang di lingkungan sekitar subjek merupakan hal yang kurang tepat. Perubahan yang terjadi pada diri subjek ini didukung oleh keinginan subjek untuk merubah sikapnya agar dapat berinteraksi dengan orang lain dan bisa bersekolah lagi seperti anak seusia subjek. Selain faktor diatas keberhasilan intervensi ini juga karena adanya dukungan dari lingkungan sekitar seperti nenek subjek, bibi subjek dan beberapa sepupu-sepupu subjek yang mendukung dan membantu agar subjek mampu untuk melaksaan intervensi ini sehingga membuat subjek merasa diterima dan merasa tidak sendiri dan banyak yang menyanyangi subjek.

Berikut ini adalah hasil perubahan subjek setelah berlangsungnya intervensi pelatihan ketrampilan sosial.

Tabel 1. Hasil Intervensi

\begin{tabular}{lll}
\hline \multicolumn{1}{c}{ Sebelum Intervensi } & \multicolumn{1}{c}{ Setelah Intervensi } & \multicolumn{1}{c}{ Sumber Data } \\
\hline Subjek sering berada di dalam & Subjek sudah mau keluar & Observasi \\
kamar dan hanya keluar saat & kamar untuk berinteraksi & \\
terapis datang & dengan orang sekitar & \\
Subjek tidak mau menyapa dan & Subjek mampu menyapa & Observasi dan Wawancara \\
menegur orang lebih dulu & dan menegur orang yang & \\
meskipun berada di dekat subjek & berada di dekatnya. & \\
Subjek kurang berkomunikasi dan & Subjek mulai terlibat dalam Observasi dan Wawancara \\
berinteraksi dengan orangyang & sebuah obrolan ringan & \\
berada di lingkungan sekitarnya & bersama temannya & \\
\hline
\end{tabular}




\section{Pembahasan}

Dalam intervensi Social Skill Training (SST) ini terapis sebagai model memberikan contoh bagaimana berinteraksi dengan lingkungan sekitar dari bagaimana cara berkenalan sampai berkomunikasi ringan dengan lingkungan sekitar yang harus subjek pelajari dan kemudian terapkan. Menurut Bandura (1986), terdapat empat proses yang terlibat di dalam pembelajaran melalui pendekatan modeling, yaitu perhatian (attention), pengendapan (retention), reproduksi (reproduction), dan penguatan (motivasi).

Pada tahap attention dan retention, yaitu tahap melihat dan penyerapan informasi subjek akan meniru tingkah laku, dan disimbolisasikan dalam ingatan, baik dalam bentuk verbal maupun dalam bentuk gambaran/imajinasi. Attention verbal memungkinkan orang mengevaluasi secara tingkah laku yang diamati, dan menentukan mana yang dibuang dan mana yang akan dicoba dilakukan. Representasi imajinasi memungkinkan dapat dilakukannya latihan simbolik dalam fikiran, tanpa benar-benar melakukannya secara fisik. Saat proses intervensi berlangsung subjek di ajarkan untuk memikirkan bahwa semua orang yang ada di sekitar subjek adalah orang yang baik dan menyenangkan.

Pada tahap produksi, individu diajarkan untuk menerapkan perilaku yang telah dipelajari ke lingkungan nyata seharihari (Bandura, 1986). Setelah mengetahui atau mempelajarai sesuatu tingkahlaku, subjek harus mempunyai keahlian untuk mewujudkan atau menghasilkan apa yang disimpan dalam bentuk tingkahlaku. Dalam proses intervensi subjek diberikan tugas oleh terapis untuk menerapkan apa yang telah terapis ajarkan dalam kehidupan subjek sehari hari. Meskipun tidak mudah tetapi karena lingkungan sekitar subjek mendukung maka tugas tersebut dapat dilaksanakan dengan baik.

Pada tahap terakhir yaitu motivasi, terapis akan membawa dan menerapkan motivasi yang tinggi terhadap subjek untuk dapat melakukan tingkahlaku modelnya. Observasi mungkin memudahkan orang untuk menguasai tingkahlaku tertentu, tetapi kalau motivasi untuk itu tidak ada, tidak bakal terjadi proses belajar. Selama proses belajar berlangsung, pemberian penguatan positif dari lingkungan sekitar dirasa mampu meningkatkan motivasi individu untuk memperkuatperilaku baru yang dipelajari (Bandura, 1989).

Secara keseluruhan, perubahan dapat terjadi karena individu telah menjalani proses belajar yang melibatkan unsur pengamatan, adanya pemberian pengetahuan mengenai konsekuensi tentang pemikiran negatifnya, dan latihan agar memperoleh keterampilan perilaku baru yang secara terus-menerus (Bandura, 1977).

\section{Kesimpulan}

Pada dasarnya subjek merupakan seseorang yang cenderung pendiam dan tertutup, subjek juga jarang berinteraksi dengan lingkungan dan lebih senang berada di dalam kamar. Teknik keterampilan sosial dengan teknik modeling terbukti efektif untuk meningkatkan keterampilan sosial subjek yang berfokuas pada meningkatkan keterampilan sosial seperti menyapa, memperkenalkan diri, berkomunikasi ringan dengan lingkungan. Hasil penelitian menunjukkan bahwa sedikit demi sedikit subjek mengalami perubahan yaitu subjek yang mampu menyapa, memperkenalkan diri terlebih dahulu bahkan mampu mengobrol ringan dengan orang yang berada di sekitar subjek sehingga subjek tidak lagi sering berada di kamar,. Subjek juga senang karena merasa dirinya tidak sendiri lagi. 


\section{DAFTAR PUSTAKA}

American Psychiatry Association. (2010). Diagnostic and Statistical Manual of Mental Disorders fifth edition. Washington DC: American Psychiatry Association.

Bandura, A. (1977). Social learning theory. New Jersey: Prentice-Hall.

Bandura, A. (1986). Social foundations of thought and action: A social cognitive theory. New Jersey: Prentice-Hall.

Bandura, A. (1989). Social cognitive theory. In R. Vasta (Ed.). Annals of child development, vol.6. Six theories of child development (pp.1-60). Greenwich, CT:JAI Press.

Corey, G. (1999). Teori dan Praktek Konseling Dan Psikoterapi. Bandung:PT Refika Aditama.

Davison, G.C \& Neale J.M. (2006). Psikologi Abnormal. Jakarta: PT. Raja Grafindo Persada.

Gimpel, G.A. \& Merrell, K.W. 1998. Social Skill of Children and Adolescents: Conceptualization, Assessment, Treatment. New Jersey: Lawrence ErlbaumAssociates Publisher.
Kendal, P.C. \& Hammen, C., 1998. Abnormal Psychology Understanding Human Problem. New York : Houghton Mifflin Company

Kneisl, C. R, Wilson, H. S. \& Trigoboff, E. (2004). Contemporary Psychiatric Mental Health Nursing New Jersey: Pearson Prentice Hall

Maramis, WF. (2009). Catatan Ilmu Kedokteran Jiwa. Surabaya: Airlangga University Press

McQuaid. (2000). Development of an integrated cognitive-bahavior and social skill training intervention for older patients with schizoprenia. The Journal of Psychotherapy Practise and Research, 9(3), 149-156.

Nevid, J., Rathus S., \& Beverly G. (2005). Psikologi Abnormal. Jakarta: Penerbit Erlangga

Varcarolis, E.M. (2006). Psychiatric Nursing Clinical Guide: AssessmentTools \& Diagnosis. Philadelphia: W.B. Saunders Company.

Stuart, G.W \& Laraia,M.T. (2005). Principles and Practice of Psychiatric Nursing. (7th Edition). St.Louis: Mosby.

Videbeck, SL. (2008). Buku Ajar Keperawatan Jiwa. Jakarta: Penerbit buku kedokteran EGC. 
